\title{
Grazing height and nitrogen fertilization strategy in black oat/maize succession
}

\section{Altura de pastejo e estratégia de adubação nitrogenada na sucessão aveia preta/milho}

\author{
Felipe Luiz Chiamulera Deifeld ${ }^{1 *}$; André Brugnara Soares ${ }^{2}$; Daniel Schmitt"; \\ Tangriani Simioni Assmann²; Regis Luis Missio2; Angélica Caroline Zatta4; Márcia \\ Mensor5; Lucas Candiotto4; Pablo Antonio Beltrán Barriga6; Felipe Candiotto ${ }^{5}$
}

\section{Highlights}

High grazing intensities significantly reduce ground cover.

Maize grain production is not affected by grazing intensities.

When applied to the pasture, there is no need to apply $N$ in the successive crop.

Maintaining black oat pasture at $20 \mathrm{~cm}$ favors animal performance.

\begin{abstract}
This study was developed to examine the effect of combining nitrogen $(\mathrm{N})$ fertilization strategies and pasture management heights on animal and grain production in an Integrated Crop-Livestock System. The experiment was carried out in the municipality of Abelardo Luz - SC, Brazil, between April 2017 and April 2018. A randomized-block design was adopted, with the treatments arranged in a $2 \times 2$ factorial arrangement with three replicates. The first factor was the height of the pasture managed under continuous grazing: high $(\mathrm{HH}, 20 \mathrm{~cm})$ or low $(\mathrm{LH}, 12 \mathrm{~cm})$. The second factor corresponded to the $\mathrm{N}$ application times: in the winter, in the pasture (NP), and in the summer, in the grain crop (NG), in a single $\mathrm{N}$ rate of $200 \mathrm{~kg} \mathrm{ha}^{-1}$ as topdressing. The forage species used during the pasture phase was black oat (Avena strigosa Schreb), and the pasture was grazed by Nellore $\times$ Charolais crossbred steers with an initial body weight of $260 \mathrm{~kg}$. The summer crop was maize (Zea mays). Average daily gain (ADG) and herbage allowance were higher in $\mathrm{HH}$ than in $\mathrm{LH}$,

1 Master in Agronomy, Universidade Tecnológica Federal do Paraná, UTFPR, Pato Branco, PR, Brazil. E-mail: felipedeifeld@gmail.com

2 Profs. PhDs., Department of Agronomy, UTFPR, Pato Branco, PR, Brazil. E-mail: soares@utfpr.edu.br; tangriani@ utfpr.edu.br; regismissio@utfpr.edu.br

3 Prof. PhD., Universidade do Estado de Santa Catarina, UDESC, Lages, SC, Brazil. E-mail: daniel.schmitt@veterinario. med.br

4 Student's Master's, Postgraduate Program in Agronomy, UTFPR, Pato Branco, PR, Brazil. E-mail: angelica_zatta@ hotmail.com; candiotto@alunos.utfpr.edu.br

${ }^{5}$ Students, Graduate in Agronomy, UTFPR, Pato Branco, PR, Brazil. E-mail: marciamensor@alunos.utfpr.edu.br; felipecandiotto@gmail.com

6 Prof. PhD., National University of the Altiplano, Puno, Peru. E-mail: pbeltran70@live.com

* Author for correspondence
\end{abstract}

Received: Sept. 29, 2020 - Approved: Mar. 08, 2021 
whereas animal load was higher in $\mathrm{HH}$. Between the $\mathrm{N}$ application times, the animal load was higher in NP. Pasture management height and $\mathrm{N}$ fertilization strategy did not affect the variables of number of rows per ear, number of grains per row, thousand-grain weight, or total grain yield, which overall averaged 14,090 kg $\mathrm{ha}^{-1}$. In conclusion, the inversion of nitrogen fertilization between the periods of winter pasture production and grain crop and the management height of the black oat pasture do not compromise the production of maize grains in the summer, or animal production per area. However, steer performance is greater (higher ADG) when the pasture is managed at $20 \mathrm{~cm}$, whereas a high grazing intensity significantly reduces straw on the soil.

Key words: Black oats. Canopy height. Nitrogen fertilization. Winter pasture. Zea mays.

\section{Resumo}

O objetivo deste estudo foi avaliar o efeito da combinação de estratégias de adubação nitrogenada e de alturas de manejo da pastagem sobre a produção animal e de grãos em um Sistema Integrado de Produção Agropecuária. O experimento foi conduzido no município de Abelardo Luz-SC, entre abril de 2017 a abril de 2018. O delineamento experimental utilizado foi blocos ao acaso e os tratamentos dispostos em arranjo fatorial $2 \times 2$ com três repetições. O primeiro fator foi a altura do pasto manejado com lotação contínua: alta altura (AA) $(20 \mathrm{~cm})$ e baixa altura (BA) $(12 \mathrm{~cm})$. O segundo fator foram as épocas de aplicação do nitrogênio: na pastagem de inverno (NP), e na cultura de grãos, no verão (NG), em dose única de $200 \mathrm{~kg} \mathrm{~N}$ $\mathrm{ha}^{-1} \mathrm{em}$ cobertura. A espécie forrageira utilizada durante a fase pastagem foi a aveia preta (Avena strigosa Schreb) e o pastejo foi realizado por novilhos cruza Nelore $x$ Charolês com peso corporal inicial de 260 kg. A cultura de verão foi o milho (Zea mays). O ganho médio diário (GMD) e a oferta de forragem foram maiores em AA comparativamente à BA, enquanto a carga animal foi maior em BA. Para as épocas de aplicação do N, a carga animal foi maior em NP. As variáveis número de fileiras por espiga, número de grãos por fileira e peso de mil grãos não foram afetadas pelo manejo da altura do pasto e nem pela estratégia de adubação nitrogenada, bem como a produção total de grãos, que apresentou média geral de 14.090 $\mathrm{kg} \mathrm{ha}^{-1}$. Concluiu-se que a inversão da adubação nitrogenada entre os períodos de produção de pasto de inverno e de cultivo de grãos, e a altura de manejo da pastagem de aveia preta não comprometem a produção de grãos de milho no verão e nem a produção animal por área. Entretanto, o desempenho dos novilhos é maior (maior GMD) quando o pasto é manejado a $20 \mathrm{~cm}$, enquanto a alta intensidade de pastejo reduz significativamente a palhada sobre o solo.

Palavras-chave: Altura de dossel. Adubação nitrogenada. Aveia preta. Pastagem de inverno. Zea mays.

\section{Introduction}

The growing demand for food production in quantity and quality, leveraged by the increasing population, is not the only concern on a global scale. The agricultural sector has been criticized for its inefficiency in the use of resources such as water and nutrients, as well as the advancement of agricultural areas in sensitive ecosystems (Moraes et al., 2018). Therefore, attention should be drawn to the different environmental, technological and social peculiarities of each region. In this respect, integrated crop-livestock systems (ICLS) emerge as an alternative to increase and diversify food 
production, ensuring food security with little negative impact on the environment (Food and Agriculture Organization of the United Nations [FAO], 2010).

Brazilian science has advanced its investigations into ICLS and shown their viability in the different regions of the national territory, with the exception of particularities of each biome. In the southern region of Brazil, ICLS are characterized by the cultivation of crops of high commercial value during the summer, such as soybean, maize and beans, whereas forages with high productive and nutritive potential such as oat (Avena spp.) and ryegrass (Lolium multiflorum Lam.) are grown in the winter. The latter are used for both animal production and ground cover, ensuring the premises of no-till planting and generating extra income for the farmer from the sale of animals (Moraes et al., 2018).

In an ICLS, factors such as grazing intensity and nitrogen (N) fertilization on the pasture are extremely important to achieve high yields and profitability. The former should be moderate, avoiding damage to the physical attributes of the soil and ensuring adequate amounts of straw (Bonetti, Paulino, Souza, Carneiro, \& Silva, 2015). Pasture fertilization is often neglected under the expectation that crop fertilization residue will be sufficient for pasture development. However, this strategy has not been effective (T. S. Assmann et al., 2018; Moraes et al., 2018; Bernardon et al., 2020). Moreover, the inversion of $\mathrm{N}$ fertilization, through the application of $\mathrm{N}$ in the grazing phase, is an interesting alternative due to the greater animal production potential, increased herbage production and efficient cycling of nutrients, which is catalyzed by the animal component. In addition, this cycling allows an adequate $\mathrm{N}$ nutrition index for the subsequent crop since the early stages of development. As a result, the application of $\mathrm{N}$ after grazing may be unnecessary, even in very demanding crops like maize (T. S. Assmann, 2001; T. S. Assmann et al., 2018).

Few studies have evaluated the interactions between the factors of pasture height and $\mathrm{N}$ fertilization (Silveira, Liu, Sollenberger, Follett, \& Vendramini, 2013), especially in ICLS (Bernardon et al., 2020). In view of this and based on the hypothesis that the inversion of $\mathrm{N}$ fertilization and the pasture management height affect animal production, but not grain yield in ICLS, this study was developed to examine different $\mathrm{N}$ fertilization strategies and pasture management heights in an ICLS.

\section{Material and Methods}

The experiment was conducted on the Pacheco farm, located in the municipality of

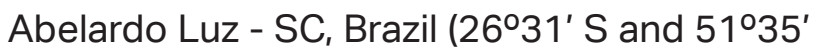
$\mathrm{W}$, approximately $850 \mathrm{~m}$ above sea level). The climate of the region is classified as a Cfb type (humid subtropical), according to the Köppen classification system (Alvares, Stape, Sentelhas, Gonçalves, \& Sparovek, 2013). During the experimental period, the maximum, minimum and average temperatures in the fall/ winter and spring/summer were 30.9, -2.8 and $15.5^{\circ} \mathrm{C}$, and $33.1,4.0$ and $19.6^{\circ} \mathrm{C}$, respectively, and the accumulated rainfall in the fall/winter and spring/summer was 653.4 and 1522.0 $\mathrm{mm}$, respectively (Figure 1). The soil in the area is classified as a typic dystric Bruno Oxisol (Empresa Brasileira de Pesquisa Agropecuária [EMBRAPA], 2013) with a very clayey texture and the presence of a prominent $A$ horizon and a latosolic $B$ horizon. The relief is classified as gently undulating. 


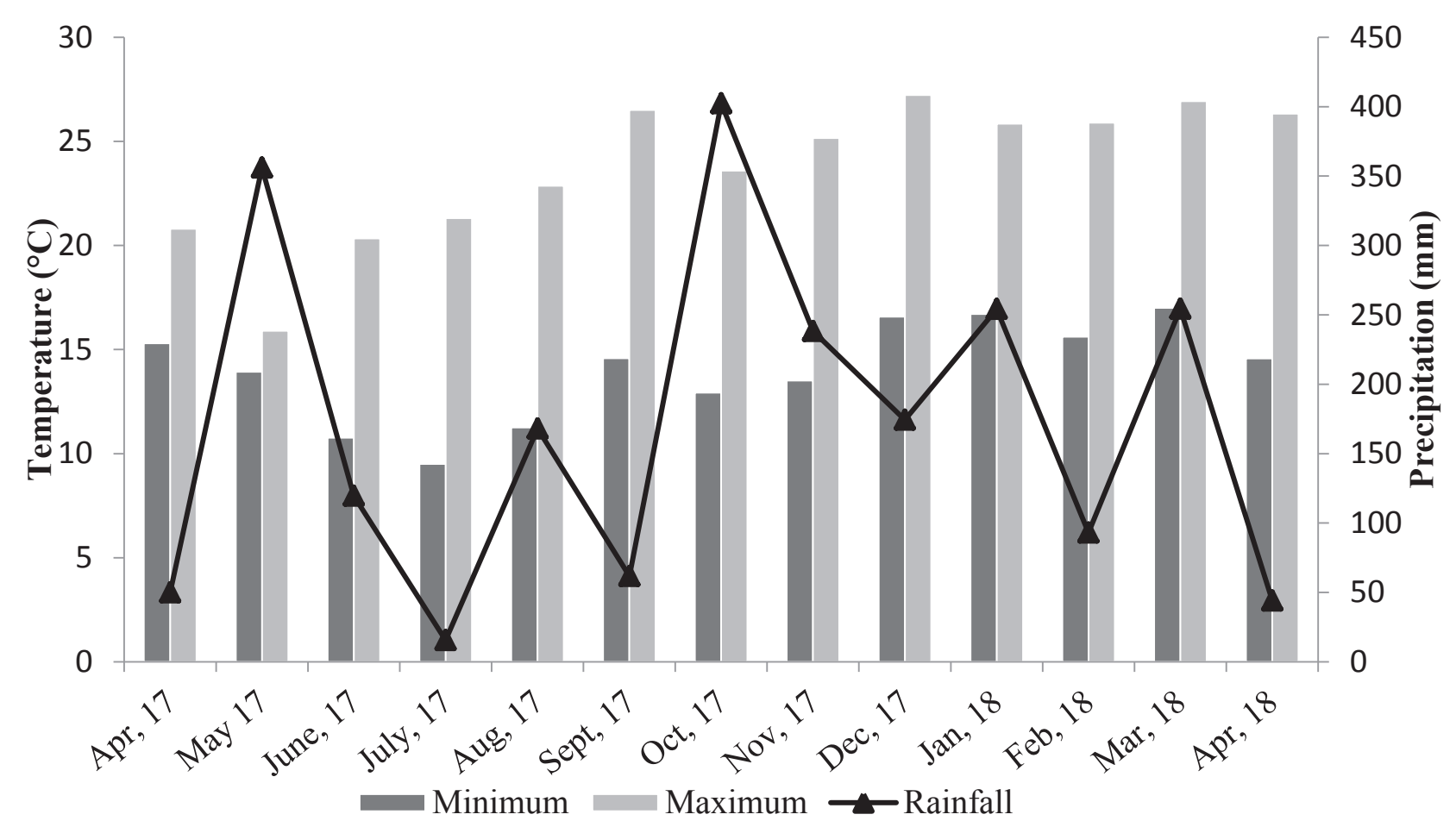

Figure 1. Monthly accumulated rainfall and monthly average maximum and minimum temperatures during the experimental period in Clevelândia - PR, Brazil, $16 \mathrm{~km}$ from the experimental area. Source: adapted from INMET, Clevelândia - PR.

The experimental area, which in the summer. From 2012, an experimental consisted of 24 ha (14 ha of experiment and 10 ha for the maintenance of grazer ['put-andtake'] animals), was maintained under minimum tillage. This farming strategy involved the sowing and covering of seeds with a harrow protocol was implemented in which the area started to be managed in an ICLS, with direct sowing of all crops, in rotation (Table 1). The soil was initially sampled up to a depth of 20 in the winter and direct planting of grain crops $\mathrm{cm}$ for routine analysis of chemical attributes. 
Table 1

Scheme of crops implemented since the establishment of the experiment in an integrated croplivestock production system, in 2012

$\begin{array}{ll}\text { Period } & \text { Crop } \\ \text { Summer 2012/2013 } & \text { Sorghum (Sorghum bicolor) } \\ \text { Winter 2013 } & \text { Common black oat (Avena strigosa) } \\ \text { Summer 2013/2014 } & \text { Grain maize (Zea mays) } \\ \text { Winter 2014 } & \text { Black oat (Avena strigosa) + ryegrass (Lolium multiflorum L.) } \\ \text { Summer 2014/2015 } & \text { Soybean (Glycine max) } \\ \text { Winter 2015 } & \text { Ryegrass (Lolium multiflorum L.) } \\ \text { Summer 2015/2016 } & \text { Maize for silage (Zea mays L.) } \\ \text { Verão 2016 } & \text { Feijão carioca safrinha (Phaseolus vulgaris) } \\ \text { Winter 2016 } & \text { Ryegrass (Lolium multiflorum L.) } \\ \text { Summer 2016/2017 } & \text { Common bean (Phaseolus vulgaris) } \\ \text { Winter 2017 } & \text { Black oat (Avena strigosa) } \\ \text { Summer 2017/2018 } & \text { Maize (Zea mays L.) }\end{array}$

A randomized-block experimental design was adopted, involving three replicates of area and four treatments in a $2 \times 2$ factorial arrangement that consisted of two pasture management heights and two $\mathrm{N}$ application times. The grazing management heights were 12 (LH: low) and $20 \mathrm{~cm}$ (HH: high), under continuous grazing, whereas the $\mathrm{N}$ application times were winter (NP: application of $\mathrm{N}$ in the pasture) and summer (NG: application of $\mathrm{N}$ in the grain crop). The $\mathrm{N}$ application times constituted a fertilization inversion, that is, the areas that were fertilized with $\mathrm{N}$ in the winter did not receive fertilization in the summer and vice-versa. The $\mathrm{N}$ rate used was $200 \mathrm{~kg} \mathrm{ha}^{-1}$, in the form of urea, in a single application. This methodology was defined at the start of the experimental protocol, aiming to measure the $\mathrm{N}$ losses in an ICLS.

The cycle prior to the experiment consisted of a pasture of ryegrass cv. Winter Star during the fall/winter of 2016 and common bean (Phaseolus vulgaris) cv. Tuiuiú during the spring/summer of 2016/2017 (Table 1). Table 2 shows the results of chemical analysis of the soil in the $0-20 \mathrm{~cm}$ layer, prior to the establishment of the pasture in 2017.

\section{Table 2}

Chemical attributes of soil at a depth of 0 to $20 \mathrm{~cm}$, from a sample collected before the start of the experimental period

\begin{tabular}{|c|c|c|c|c|c|c|c|c|c|c|}
\hline $\mathrm{pH}$ & $\mathrm{OM}$ & P & $\mathrm{K}^{+}$ & $\mathrm{Ca}^{2+}$ & $\mathrm{Mg}^{2+}$ & $\mathrm{Al}^{3+}$ & $\mathrm{H}+\mathrm{Al}$ & SB & CEC & BS \\
\hline $\mathrm{CaCl}_{2}$ & $\mathrm{~g} \mathrm{dm}^{-3}$ & $\mathrm{mg} \mathrm{d}^{-3}$ & & & & nol & & & & $\%$ \\
\hline 4.7 & 51.71 & 14.37 & 0.44 & 4.36 & 2.24 & 0.13 & 7.19 & 7.04 & 14.23 & 49.47 \\
\hline
\end{tabular}

Soil analysis laboratory UTFPR-PB/IAPAR. Methodologies: OM by wet digestion; P and K + extracted with Mehlich 1 solution; $\mathrm{pH}$ in $\mathrm{CaCl}_{2}$ 1: 2.5; Exchangeable $\mathrm{Ca}^{2+}, \mathrm{Mg}^{2+}$ and $\mathrm{Al}^{3+}$ extracted with $\mathrm{KCl} 1 \mathrm{~mol} \mathrm{~L}^{-1}$. 
On April 28, 2017, the 'common' black oat pasture was sown at a density of $59 \mathrm{~kg}$ ha $^{-1}$ of pure, viable seeds, $17 \mathrm{~cm}$ spacing between rows and a sowing depth of $3 \mathrm{~cm}$. Basal fertilization consisted of $60 \mathrm{~kg} \mathrm{ha}^{-1} \mathrm{P}_{2} \mathrm{O}_{5}$ (330 kg ha-1 single superphosphate) in the row at sowing. Potassium (K) was broadcast at the rate of $85 \mathrm{~kg} \mathrm{ha}^{-1} \mathrm{KCl}$, after the emergence of the oat seedlings, on May 15, 2017.

The paddocks under the NP treatment were top-dressed with $200 \mathrm{~kg} \mathrm{~N} \mathrm{ha}^{-1}$ on May 25,2017 , during the tillering of the oat plants, in a single application, using urea $(45 \% \mathrm{~N})$ as the $\mathrm{N}$ source. The other half of the paddocks (NG) received $\mathrm{N}$ fertilization in the crop that preceded the pasture, which was common bean (100 kg N ha-1 as topdressing). The dose used in common bean differs from historical doses because this crop provides a good part of $\mathrm{N}$ through biological fixation and high $\mathrm{N}$ rates could affect symbiosis (Brito, Muraoka, \& Silva, 2011).

The grazing period began on June 13 2017, when the plants reached an average height of $20 \mathrm{~cm}$. The grazing method adopted was continuous with a variable stocking rate, and the management criterion was the maintenance of the two grazing heights. Three test animals were initially allocated to each paddock. The test animals were castrated steers from the cross between the Nellore and Charolais breeds, with an initial average body weight of $260 \pm 69 \mathrm{~kg}$ and approximately 12 months of age. The animals were weighed immediately before and after the grazing period and were deprived of solid and liquid feed during the $24 \mathrm{~h}$ prior to weighing. All steers had free access to water and mineral salt.

To ensure the heights specified for the treatments, measurements were performed once weekly, at 40 points per paddock. The grazing period was until August 27, 2017, totaling 75 days, and the pasture was desiccated on August 29, 2017. Due to a drought period, the maize was sown 36 days after pasture desiccation (10/04/2017). Maize hybrid AG 9025 VTPRO3 was sown at a density of 3.5 seeds $\mathrm{m}^{-1}$, with $45 \mathrm{~cm}$ spacing between rows, totaling approximately 78,000 plants ha-1.

Basal fertilization consisted of the application of $150 \mathrm{~kg} \mathrm{ha}^{-1}$ MAP ( $8 \%$ ammoniacal Nand $40 \% \mathrm{P}_{2} \mathrm{O}_{5}$ ) in the planting row, immediately below the seed deposition. When the maize plants were at the $\mathrm{V} 5$ stage, a N rate of $200 \mathrm{~kg}$ $\mathrm{ha}^{-1}$ was applied as topdressing, in the form of urea $(45 \% \mathrm{~N})$, only in the NG treatment plots. After fertilizer application, sufficient rainfall occurred for the $\mathrm{N}$ to be incorporated into the soil (> $20 \mathrm{~mm}$ ), which resulted in low urea $\mathrm{N}$ losses due to the soil and moisture conditions (Hargrove, 1988). Pests, diseases and weeds were controlled chemically throughout the development of the crop.

The data of the variables analyzed in the pasture phase are the result of the average of three data collection periods, consisting of two 28-day and one 19-day periods. The proportions of leaf blades (LB), stems + sheath (SS) and senescent material (SM) were estimated by cutting the herbage close to soil level at six sampling points per experimental unit (EU, paddock), in a $0.17-\mathrm{m}^{2}$ area. Subsequently, the material was partitioned into LF, SS and SM, which were dried and weighed. The nutritional value of the herbage was determined by collecting one herbage sample per EU, using the simulated-grazing technique (Johnson, 1978). This was followed by analysis of the crude protein (CP) content, by the micro Kjeldhal method (Association of Official Analytical Chemists [AOAC], 1995), 
and neutral (NDF) and acid detergent fiber (ADF) by the fiber partition method proposed by Van Soest (1994). Herbage mass (HM) was measured by cutting close to the soil of the canopy at six $0.25-\mathrm{m}^{2}$ points per EU, followed by drying and weighing. Herbage accumulation rate (HAR) was calculated by the double-pairing technique, with the allocation of grazing exclusion cages (Klingman, Miles, \&
Mott, 1943). The remaining post-grazing straw was quantified using the result of $\mathrm{HM}$ after the animals were withdrawn from the experimental area.

The following animal production variables were determined:

- Animal load (AL, kg of body weight [BW] ha $^{-1}$ ), obtained by the formula below:

$$
A L=\left(\sum A W t a+\frac{\left(A W g a_{1} * D_{1}+\cdots+A W g a_{n} * D_{n}\right)}{D t}\right) * \frac{10000}{P A}
$$

where $A W t a=$ average weight of the test animals (kg); $A W g a$ = average weight of each grazer animal during its stay in the paddock $(\mathrm{kg}) ; D=$ number of days each grazer animal spent in the paddock; $D t=$ total number of grazing days; and $P A=$ paddock area $\left(\mathrm{m}^{2}\right)$.
- Herbage allowance (HA, kg of dry matter [DM] $\mathrm{kg}^{-1} \mathrm{BW}$ ), obtained by adapting the formula described by Sollenberger, Moore, Allen and Pedreira (2005):

$$
H A=\frac{\left(\frac{\left(I H M_{P 1}+F H M_{P 1}\right) / 2}{A L_{P 1}} * D_{1}+\cdots+\frac{\left(I H M_{p n}+F H M_{p n}\right) / 2}{A L_{p n}} * D_{n}\right)}{D t}
$$

where $I H M=$ initial herbage mass $(\mathrm{kg} D M$ ha 1) for each period; $F H M=$ final herbage mass (kg DM ha-1) for each period; $A L=$ animal load for each period; $D=$ number of days in each period; and $D t=$ total number of grazing days.

- Average daily gain (ADG, kg BW day $^{-1}$ ), obtained as the ratio between the difference in the final and initial weight of the test animals and the total number of grazing days.

- Weight gain per area (WGA, kg BW ha1), obtained by the following formula:

$$
W G A=A D G * \frac{A L}{A W} * D t
$$

where $A D G$ = average daily gain; $A L$ = animal load; $A W=$ average weight of the animals per paddock; and Dt = total number of grazing days.
In the maize crop, four evaluations were performed when the plants reached physiological maturity. To determine the number of rows per ear and grains per row, 32 ears were randomly collected per EU and quantified in the laboratory. Thousandgrain weight and total grain yield (TGY) were measured by randomly selecting 10 rows per EU and collecting all ears present in two linear meters in each row. All grains from these ears were detached and dried to remove excessive moisture. The samples were weighed and the result was adjusted to a moisture content of $15 \%$.

Data were subjected to the Kolmogorov-Smirnov normality test by the PROC UNIVARIATE procedure of SAS software (v. 9.0). Once this assumption was met, the 
data were subjected to analysis of variance using the PROC MIXED procedure of SAS (v. 9.0), considering pasture height and $N$ fertilization time as fixed effects and the area replicates as random. Means were compared using Student's " $t$ " test, considering $5 \%$ as the critical level of significance.

\section{Results and Discussion}

There was no interaction effect between pasture management heights and $\mathrm{N}$ application times for the studied variables. Thus, the effects of the variation factors will be presented separately.

Herbage mass was $68.2 \%$ higher in $\mathrm{HH}$ than in LH ( $P=0.0024)$ (Table 3). This result was expected, given that this information is available in the literature (Aguinaga et al., 2008; Carvalho et al., 2010; Wesp et al., 2016). These studies showed that each $1 \mathrm{~cm}$ increase in canopy height above $10 \mathrm{~cm}$ corresponded to an increase of $86.3,107$ and $85.4 \mathrm{~kg}$ DM $\mathrm{ha}^{-1}$ in HM, respectively. To reach the pasture management target based on canopy height, the $\mathrm{AL}$ in the $\mathrm{LH}$ treatment had to be increased. This led to a greater disappearance of herbage (consumption and trampling losses), which explains the lower HM in that treatment.

Considering that the HM in a continuous grazing system increases or decreases as a function of the balance between herbage appearance and disappearance, HAR could be used to explain the HM. According to Nunes et al. (2018), moderate grazing provides higher HAR than intensive grazing. However, there were no differences between the HAR in the present study. Therefore, the explanation for the lower HM in the LH treatment being due to the higher $\mathrm{AL}$ is reinforced.

\section{Table 3}

Canopy structure variables and herbage production in 'common' black oat pasture under two pasture management heights and two nitrogen application times

\begin{tabular}{ccccccc}
\multicolumn{7}{c}{ Pasture management height } \\
& HM & LB & SS & SM & HAR & Straw \\
HH & $2,860 \mathrm{~A}$ & 36.5 & 26.4 & 37.2 & 70.4 & $1,450 \mathrm{~A}$ \\
LH & $1,700 \mathrm{~B}$ & 35.5 & 22.2 & 42.3 & 65.4 & $640 \mathrm{~B}$ \\
\multicolumn{7}{c}{ Nitrogen application time } \\
NG & HM & LB & SS & SM & HAR & Straw \\
NP & 2,250 & 33.3 & 24.0 & 44.8 & 52.7 & 1,060 \\
& 2,310 & 38.7 & 24.6 & 36.7 & 83.1 & 1,040
\end{tabular}

$\mathrm{LH}=$ low height $(12 \mathrm{~cm})$ and $\mathrm{HH}=$ high height $(20 \mathrm{~cm}) . \mathrm{NG}=$ nitrogen applied to the grain crop during the summer and $\mathrm{NP}$ = nitrogen applied to the pasture during the winter. $\mathrm{HM}=$ herbage mass $\left(\mathrm{kg} \mathrm{DM} \mathrm{ha}^{-1}\right) ; \mathrm{LF}=$ leaf blades (\%); SS = stems + sheath (\%); SM = senescent material (\%); HAR = herbage accumulation rate $\left(\mathrm{kg} \mathrm{DM} \mathrm{ha}^{-1}\right.$ day $\left.^{-1}\right) ;$ Straw $\left(\mathrm{kg} \mathrm{DM} \mathrm{ha}^{-1}\right) ; \mathrm{Means}$ followed by different uppercase letters in the column differ by Student's t test at $5 \%$ probability. 
The residual straw was $126.6 \%$ more in $\mathrm{HH}$ than in $\mathrm{LH}(\mathrm{P}=0.0041$ ) (Table 3). This result was already expected, since this variable is represented by the final HM. In this study, the residual straw after grazing was low (1450 and $640 \mathrm{~kg} \mathrm{DM} \mathrm{ha}^{-1}$ for the pasture heights of 20 and $12 \mathrm{~cm}$, respectively) when compared with the results obtained by Kunrath et al. (2020), who described that the average of 16 years of an oat and ryegrass pasture generated 3377 and $1500 \mathrm{~kg} \mathrm{DM} \mathrm{ha}^{-1}$ at the canopy heights of 20 and $10 \mathrm{~cm}$, respectively. Although grazing sometimes does not allow the necessary amount of straw, even at moderate intensities, it is important to consider that the root biomass of the pasture can increase considerably, benefiting the carbon uptake along the soil profile (Souza et al., 2008). It should be noted that during the grazing period, there were strong frosts and a period of drought that limited pasture production.

The effect of $\mathrm{N}$ application times on the variables evaluated in the pasture phase was observed only in the crude protein (CP) content, which was $37.4 \%$ higher in NP than in NG $(P<0.0001)$ (Table 4). This can be explained by the fact that $\mathrm{N}$ is a fundamental constituent of amino acids, which, in turn, are fundamental units for protein formation (Taiz \& Zeiger, 2013). In this way, the greater availability of $N$ in the NP treatment caused the CP of the pastures to increase. This result corroborates literature data that indicate that the $\mathrm{CP}$ content of the pasture has a positive correlation with the N doses (Lupatini, Restle, Ceretta, Moojen, \& Bartz, 1998; Andrade, Fonseca, Queiroz, Salgado, \& Cecon, 2003; Loaiza, Balocchi, \& Bertrand, 2016).
Herbage allowance and ADG were $105.6 \%(P<0.0001)$ and $23.4 \%(P=0.0164)$ higher, respectively, when the pasture was kept under $\mathrm{HH}$ (Table 5). However, even in LH, ADG was high (average $1.11 \mathrm{~kg} \mathrm{BW}$ animal ${ }^{-1}$ day $^{-1}$ ) when compared with literature data (Lupatini et al., 2013; Wesp et al., 2016; Kunrath et al., 2020). This can be explained by the $\mathrm{HA}$, whose value (1.8 $\mathrm{kg} \mathrm{DM} \mathrm{kg}^{-1}$ of $\mathrm{BW}$ ) was higher than that considered limiting to animal intake (1 kg DM kg-1 BW) (Wesp et al., 2016). Moreover, the grazing period in this study was relatively short (75 days) and, during this time, the pasture remained in a vegetative stage, with greater nutritional value, considering that a drop was expected at the end of the cycle (Paris et al., 2012). In herbivores farmed extensively, weight gain can be explained by the nutritional value, $\mathrm{HA}, \mathrm{HM}$ and structure of the pasture, which allows the animal to select a high-quality diet (Carvalho, Ribeiro, Poli, Moraes, \& Delagarde, 2001). In this study, there was no difference in nutritional value and morphological composition between the pasture heights. Therefore, some situations can explain the difference in ADG between the pasture management heights, e.g.: i) in canopies with a low height, grazing is characterized by a smaller bite area and mass, which translates into a greater number of bites and a longer grazing time (Carvalho et al., 2001; Baggio et al., 2009), causing greater energy expenditure; ii) with the higher $\mathrm{HA}$ in the $\mathrm{HH}$ treatment, greater selection was possible, allowing preferential ingestion of tissues of better nutritional quality, such as leaves (Carvalho et al., 2001); and iii) greater total herbage intake potential, since a taller pasture provides a greater bite depth (Carvalho et al., 2001). 


\section{Table 4}

Nutritional value in 'common' black oat pasture under two pasture management heights and two nitrogen application times

\begin{tabular}{|cccc|}
\hline & \multicolumn{2}{c|}{ Pasture management height } & ADF \\
\hline HH & CP & NDF & 26.4 \\
LH & 23.9 & 46.5 & 26.0 \\
\hline & 25.0 & 45.7 & ADF \\
\hline NG & \multicolumn{2}{c}{ Nitrogen application time } & 26.7 \\
NP & CP & NDF & 25.6 \\
\hline
\end{tabular}

$\mathrm{LH}=$ low height $(12 \mathrm{~cm})$ and $\mathrm{HH}=$ high height $(20 \mathrm{~cm}) . \mathrm{NG}=$ nitrogen applied to the grain crop during the summer and NP = nitrogen applied to the pasture during the winter. $\mathrm{CP}=$ crude protein (\%); NDF = neutral detergent fiber (\%) and ADF $=$ acid detergent fiber (\%). Means followed by different uppercase letters in the column differ by Student's $t$ test at $5 \%$ probability.

\section{Table 5}

Animal weight gains (daily and per area), animal load and herbage allowance in 'common' black oat pasture under two pasture management heights and two nitrogen application times

\begin{tabular}{ccccc} 
& \multicolumn{5}{c}{ Pasture height } \\
AA & ADG & AL & WGA & HA \\
BA & $1.37 \mathrm{~A}$ & $717.2 \mathrm{~B}$ & 243.2 & $3.7 \mathrm{~A}$ \\
& $1.11 \mathrm{~B}$ & $1.079 .2 \mathrm{~A}$ & 281.3 & $1.7 \mathrm{~B}$ \\
& $\mathrm{~T}$ & Nitrogen application time & HA \\
NG & ADG & AL & WGA & 3.0 \\
NP & 1.32 & $792.9 \mathrm{~B}$ & 243.8 & 2.4
\end{tabular}

$\mathrm{LH}=$ low height $(12 \mathrm{~cm})$ and $\mathrm{HH}=$ high height $(20 \mathrm{~cm}) . \mathrm{NG}=$ nitrogen applied to the grain crop during the summer and NP $=$ nitrogen applied to the pasture during the winter. $A D G=$ average daily weight gain ( $\mathrm{kg} \mathrm{BW}$ day ${ }^{-1} ; \mathrm{BW}=$ body weight); $\mathrm{AL}$ $=$ animal load $\left(\mathrm{kg} \mathrm{BW} \mathrm{ha}^{-1}\right)$; WGA = weight gain per area $\left(\mathrm{kg} \mathrm{BW} \mathrm{ha}^{-1}\right)$ and $\mathrm{HA}=$ herbage allowance $\left(\mathrm{kg} \mathrm{BW} \mathrm{kg}^{-1} \mathrm{BW}\right)$. Means followed by different uppercase letters in the column differ by Student's $t$ test at $5 \%$ probability.

Animal load was $42.1 \%$ higher ( $P$ $=0.0004)$ in $\mathrm{LH}$ than in $\mathrm{HH}$, whereas WGA showed no significant difference between the pasture heights. This variable averaged 281.3 and $243.2 \mathrm{~kg} \mathrm{BW} \mathrm{ha}^{-1}$ in $\mathrm{LH}$ and $\mathrm{HH}$, respectively, which were lower than the 544 and $423 \mathrm{~kg} \mathrm{BW} \mathrm{ha}^{-1}$ described by Kunrath et al. (2020) for the grazing heights of 10 and 20 $\mathrm{cm}$, respectively, in oat and ryegrass pasture in an ICLS. In addition to the difference in plant composition, the grazing period in the present study was shorter than that adopted by the above-mentioned authors (75 and 125 days, respectively), which caused the total animal production per area to be limited. 
The nitrogen application times did not significantly influence HA or WGA, whereas $A L$ was $26.6 \%$ higher in NP $(P=0.0058$ ) (Table 5). The animal production values (243.8 and $280.6 \mathrm{~kg} \mathrm{BW} \mathrm{ha}^{-1}$ for NG and NP, respectively) were similar to the average of three years of evaluation in an ICLS located in Ponta Grossa$\mathrm{PR}$, Brazil, where the researchers obtained 255 and $292.5 \mathrm{~kg} \mathrm{BW} \mathrm{ha}^{-1}$ for fertilization with 90 and $180 \mathrm{~kg} \mathrm{~N} \mathrm{ha}^{-1}$, respectively, in black oat and ryegrass pasture (data adjusted for 75 days of grazing) (Pontes et al., 2018).

Animal production per area showed significant variations in the ICLS, which are due, among other factors, to the use or nonuse of $\mathrm{N}$ fertilization in the pasture; the way the animal accesses and uses the pasture; as well as herbage production (Balbinot, Moraes, Veiga, Pelissari, \& Dieckow, 2009). It is worth mentioning that, in the present study, specifically in the month of July, there were temperatures below $0{ }^{\circ} \mathrm{C}$ and the formation of frosts, followed by a drought period (Figure $1)$, which significantly compromised pasture production, due mainly to tissue dehydration (Cober, Macrae, \& Van Eerd, 2018). As a consequence, the animal load had to be adjusted.

We believe that if the grazing period had been longer and herbage production not limited due to climatic conditions, WGA would have been higher in the LH and NP treatments than in $\mathrm{HH}$ and $\mathrm{NG}$, as in the cycles prior to this study (unpublished data) and as also described in the literature (A. L. Assmann et al., 2004; Lupatini et al., 2013; Kunrath et al., 2020).

The studied variables of the maize crop did not respond to the tested treatments (Table 6). The average maize grain yield in this study was $14,090 \mathrm{~kg} \mathrm{ha}^{-1}$, which exceeds the average yields of 7,997 and 8,748 kg ha $^{-1}$ from the states of Santa Catarina and Paraná, respectively, in the 2017/2018 crop (Companhia Nacional de Abastecimento [CONAB], 2018). The high yield obtained in this study may be linked to the fact that the area was managed in an ICLS. According to Moraes et al. (2014), areas grazed in the winter exhibit higher grain production in the summer than ungrazed areas, as they reported in an evaluation of 23 studies conducted in ICLS in different regions of the Brazilian subtropics. The authors highlighted some factors that determine the higher grain yield in areas managed in an ICLS as compared with areas that are not grazed, e.g., increases in soil carbon content, biomass, microbial diversity, phosphorus availability, among others.

For the $\mathrm{N}$ application times, the cycling of nutrients in ICLS was found to be a relevant factor that should be explored (Carvalho et al., 2018), since by applying $N$ at high levels in the pasture during the winter, under grazing, it is possible to dispense with the application of $\mathrm{N}$ in the successive grain crop. The grain yield of the maize that received $200 \mathrm{~kg} \mathrm{~N} \mathrm{ha}^{-1}$ as topdressing was equal to the yield of the maize that was not top-dressed. The lack of response from maize to $\mathrm{N}$ fertilization (Table 6 - TGY variable) is explained by the high yield of the maize grown in the pasture that received the same $200 \mathrm{~kg} \mathrm{~N} \mathrm{ha}^{-1}$ and that recycled most of the nutrients, providing nutrition conditions for high productivity to the following maize. The fact that summer crops respond to the fertilization applied in the previous pasture in the same way that they respond in productivity to the fertilization applied on them has already been reported by other authors (T. S. Assmann et al., 2003; Bernardon et al., 2020). 


\section{Table 6}

Number of rows per ear, number of grains per row, thousand-grain weight and maize grain yield in an ICLS under two pasture management heights and two nitrogen application times

\begin{tabular}{ccccc} 
& \multicolumn{4}{c|}{ Pasture height } \\
Rows & G/R & TGW & TGY \\
BA & 14.5 & 36.3 & 385 & 13,950 \\
& 14.3 & 35.8 & 385 & 14,230 \\
NG & Rows & Nitrogen application time & TGY \\
NP & 14.5 & G/R & TGW & 14,240 \\
& 14.3 & 35.3 & 390 & 13,940 \\
\hline
\end{tabular}

$\mathrm{LH}=$ low height $(12 \mathrm{~cm})$ and $\mathrm{HH}=$ high height $(20 \mathrm{~cm}) . \mathrm{NG}=$ nitrogen applied to the grain crop during the summer and NP = nitrogen applied to the pasture during the winter. Rows = number of rows per ear; $\mathrm{G} / \mathrm{R}$ = number of grains per row; TGW $=$ thousand-grain weight $(\mathrm{g})$ and TGY = total maize grain yield $\left(\mathrm{kg} \mathrm{ha}^{-1}\right)$. Means followed by different uppercase letters in the column differ by Student's $t$ test at $5 \%$ probability.

The present results regarding the pasture management heights must be analyzed with caution. Because the different canopy heights in the winter did not influence grain yield in the summer or animal production per area, it appears that managing the pasture at 12 or $20 \mathrm{~cm}$ would generate equal results. Nonetheless, it is important to emphasize that the grazing period in this study was relatively short. Accordingly, the obtained results do not represent the consequences of more intensive grazing in the long term, which, in general, compromise the system balance (Carvalho et al., 2018; Bonetti, Anghinoni, Gubiani, Cecagno, \& Moraes, 2019). Thus, moderate grazing should be recommended, as it allows for viable animal production and ensures the ideal ground cover (Kunrath et al., 2020).

Among the negative consequences of more severe grazing, Bonetti et al. (2015) mentioned the reduced contribution of dry shoot biomass to the system, alteration of total porosity and increased mechanical penetration resistance of the soil. However, these authors did not observe differences in the yield of soybean in response to grazing intensities or no grazing, which the current findings also corroborate.

Finally, it is important to note that the present study evaluates only one grazing cycle and one grain harvest, rendering the conclusions specific to this setting. We also emphasize the need for new studies involving longer periods of evaluation, which will make it possible to analyze the effects of treatments and climatic variations over the years.

\section{Conclusions}

In the soil-climatic and management conditions adopted in this experiment, the inversion of nitrogen fertilization and the management height of black oat pasture do not compromise maize grain production during the summer or steer productivity in the winter. However, steer performance is greater when the black oat pasture is managed at a height of 
$20 \mathrm{~cm}$, whereas a high grazing intensity (lower height) reduces the amount of straw on the soil.

\section{Acknowledgments}

The authors thank the Araucária Foundation for the fellowship grant; and CAPES, for the fellowship grant awarded to the new doctors through the National PostDoctorate Program (PNPD).

\section{References}

Aguinaga, A. A. Q., Carvalho, P. C. F., Anghinoni, I., Pilau, A., Aguinaga, A. J. Q., \& Gianluppi, G. D. F. (2008). Componentes morfológicos e produção de forragem de pastagem de aveia e azevém manejada em diferentes alturas. Revista Brasileira de Zootecnia, 37(9), 1523-1530. doi: 10.1590/S1516-35 982008000900002

Alvares, C. A., Stape, J. L., Sentelhas, P. C., Gonçalves, J. L. M., \& Sparovek, G. (2013). Koppen's climate classification map for Brazil. Meteorologische Zeitschrift, 22(6), 711-728. doi: 10.1127/0941-2948/2013/ 0507

Andrade, A. C., Fonseca, D. M., Queiroz, D. S., Salgado, L. T., \& Cecon, P. R. (2003). Adubação nitrogenada e potássica em capim-elefante (Pennisetum purpureum schum. cv. napier). Ciência e Agrotecnologia, 27(Edição Especial), 1643-1651.

Assmann, A. L., Pelissari, A., Moraes, A., Assmann, T. S., Oliveira, E. B., \& Sandini, I. (2004). Produção de gado de corte e acúmulo de matéria seca em sistema de integração lavoura-pecuária em presença e ausência de trevo branco e nitrogênio. Revista Brasileira de Zootecnia, 33(1), 37-44. doi: 10.1590/S15 16-35982004000100006

Assmann, T. S. (2001). Rendimento de milho em área de integração lavoura-pecuária sob o sistema de plantio direto, em presença e ausência de trevo branco, pastejo e nitrogênio. Tese de doutorado, Universidade Federal do Paraná, Curitiba, PR, Brasil.

Assmann, T. S., Martinichen, D., Lima, R. C., Huf, F. L., Zortea, T., Assmann, A. L.,... Alves, S. J. (2018). Adubação de sistemas e ciclagem de nutrientes em sistemas integrados de produção agropecuária. In E. D. Souza, F. D. Silva, T. S. Assmann, M. A. C. Carneiro, P. C. F. Carvalho, \& H. B. Paulino (Eds.), Sistemas integrados de produção agropecuária no Brasil (pp. 123-144). Tubarão, SC: Copiart.

Assmann, T. S., Ronzelli, P., Jr., Moraes, A., Assmann, A. L., Koehler, H. S., \& Sandini, I. (2003) Rendimento de milho em área de integração lavoura-pecuária sob o sistema plantio direto, em presença e ausência de trevo branco, pastejo e nitrogênio. Revista Brasileira de Ciência do Solo, 27(4), 675-683. doi: 10.1590/S0 100-06832003000400012

Association of Official Analytical Chemists (1995). Official methods of analysis of the Association of the Analytical Chemists (16nd ed.). Washington: AOAC.

Baggio, C., Carvalho, P. C. F., Silva, J. L. S. D., Anghinoni, I., Lopes, M. L. T., \& Thurow, J. M. (2009). Padrões de deslocamento e captura de forragem por novilhos em pastagem de azevém-anual e aveiapreta manejada sob diferentes alturas 
em sistema de integração lavourapecuária. Revista Brasileira de Zootecnia, 38(2), 215-222. doi: 10.1590/S1516-35 982009000200001

Balbinot, A. A., Jr., Moraes, A. D., Veiga, M. D., Pelissari, A., \& Dieckow, J. (2009). Integração lavoura-pecuária: intensificação de uso de áreas agrícolas. Ciência Rural, 39(6), 1925-1933. doi: 10.1590/S0103-84782009005000107

Bernardon, A., Assmann, T. S., Soares, A. B., Franzluebbers, A., Maccari, M., \& Bortolli, M. A. (2020). Carryover of $\mathrm{N}$-fertilization from corn to pasture in an integrated crop-livestock system. Archives of Agronomy and Soil Science, 66(1), 1-16. doi: 10.1080/03650340.2020.1749268

Bonetti, J. A., Anghinoni, I., Gubiani, P. I., Cecagno, D., \& Moraes, M. T. de. (2019). Impact of a long-term crop-livestock system on the physical and hydraulic properties of an Oxisol. Soil and Tillage Research, 186(1), 280-291. doi: 10.1016/j. still.2018.11.003

Bonetti, J. A., Paulino, H. B., Souza, E. D. D., Carneiro, M. A. C., \& Silva, G. N. D. (2015). Influência do sistema integrado de produção agropecuária no solo e na produtividade de soja e braquiária. Pesquisa Agropecuária Tropical, 45(1), 104-112. doi: 10.1590/1983-40632015v 4529625

Brito, M. D. M. P., Muraoka, T., \& Silva, E. C. D. (2011). Contribuição da fixação biológica de nitrogênio, fertilizante nitrogenado e nitrogênio do solo no desenvolvimento de feijão e caupi. Bragantia, 70(1), 206215. doi: 10.1590/S0006-870520110001 00027
Carvalho, P. C. F., Barro, R. S., Barth, A., Neto, Nunes, P. A. A., Moraes, A., Anghinoni, I.,... Borin, J. B. M. (2018). Integrating the pastoral component in agricultural systems. Revista Brasileira de Zootecnia, 47, e20170001. doi: 10.1590/rbz472017 0001

Carvalho, P. C. F., Ribeiro, H. M. N., Fo., Poli, C. H. E. C., Moraes, A. D., \& Delagarde, R. (2001). Importância da estrutura da pastagem na ingestão e seleção de dietas pelo animal em pastejo. In W. R. S. Mattos (Org.), A produção animal na visão dos brasileiros (pp. 853-871). Piracicaba-SP: FEALQ.

Carvalho, P. C. F., Rocha, L. M. D., Baggio, C., Macari, S., Kunrath, T. R., \& Moraes, A. D. (2010). Característica produtiva e estrutural de pastos mistos de aveia e azevém manejados em quatro alturas sob lotação contínua. Revista Brasileira de Zootecnia, 39(9), 1857-1865. doi: 10. 1590/S1516-35982010000900001

Cober, J. R., Macrae, M. L., \& Van Eerd, L. L. (2018). Nutrient release from living and terminated cover crops under variable freeze-thaw cycles. Agronomy Journal, 110(3), 1036-1045. doi: 10.2134/agronj20 17.08.0449

Companhia Nacional de Abastecimento (2018). Acompanhamento da safra brasileira: grãos. Brasília, DF: CONAB.

Empresa Brasileira de Pesquisa Agropecuária (2013). Sistema brasileiro de classificação de solos. Rio de Janeiro: Centro Nacional de Pesquisa de Solos.

Food and Agriculture Organization of the United Nations (2010). An internacional consultation on integrated crop-livestock systems for development: the way forward 
for sustainable production intensification. Rome: FAO.

Hargrove, W. I. (1988). Soil environmental and management factors influencing ammonia volatilization under field conditions. In B. R. Bock, \& D. E. Kissel (Eds.), Ammonia volatilization from urea fertilizers (pp. 1736). Alabama: NFDC, TVA.

Johnson, A. D. (1978). Sample preparation and chemical analysis of vegetation. In Manetje, L. (Ed.), Measurement of grassland vegetation and animal production (pp. 96-102). Aberustwyth: Commonwealth Agricultural Bureaux.

Klingman, D. L., Miles, S. R., \& Mott, G. O. (1943). The cage method for determining consumption and yield of pasture herbage. Journal of the American Society of Agronomy, 35(9), 739-747. doi: 10.2134/agronj1943.000219620035000 $90001 x$

Kunrath, T. R., Albuquerque Nunes, P. A. de, Souza, W. de, Fo., Cadenazzi, M., Bremm, C., Martins, A. P., \& Carvalho, P. C. F (2020). Sward height determines pasture production and animal performance in a long-term soybean-beef cattle integrated system. Agricultural Systems, 177(1), 102716. doi: 10.1016/j.agsy.2019.102716

Loaiza, P. A., Balocchi, O., \& Bertrand, A. (2016). Carbohydrate and crude protein fractions in perennial ryegrass as affected by defoliation frequency and nitrogen application rate. Grass and Forage Science, 72(3), 556-567. doi: 10.1111/gfs. 12258

Lupatini, G. C., Restle, J., Ceretta, M., Moojen, E. L., \& Bartz, H. R. (1998). Avaliação da mistura de aveia preta e azevém sob pastejo submetida a níveis de nitrogênio. Pesquisa Agropecuária Brasileira, 33(11), 1939-1944.

Lupatini, G. C., Restle, J., Vaz, R. Z., Valente, A. V., Roso, C., \& Vaz, F. N. (2013). Produção de bovinos de corte em pastagem de aveia preta e azevém submetida à adubação nitrogenada. Ciência Animal Brasileira, 14(2), 164-171. doi: 10.5216/ cab.v14i2.21068

Moraes, A., Carvalho, P. C. F., Anghinoni, I., Lustosa, S. B. C., Andrade, S. E. V. G. de, \& Kunrath, T. R. (2014). Integrated crop-livestock systems in the Brazilian subtropics. European Journal of Agronomy, 57(1), 4-9. doi: 10.1016/j.eja. 2013.10.004

Moraes, A., Carvalho, P. C. F., Pelissari, A., Anghinoni, I., Lustosa, S. B. C., Lang, C. R.,... Nunes, P. A. A. (2018). Sistemas integrados de produção agropecuária: conceitos básicos e histórico no Brasil. In E. D. Souza, F. D. Silva, T. S. Assmann, M. A. C. Carneiro, P. C. F. Carvalho, \& H. B. Paulino (Eds.), Sistemas integrados de produção agropecuária no Brasil (pp. 1328). Tubarão: Copiart.

Nunes, P. A. D. A., Bredemeier, C., Bremm, C., Caetano, L. A. M., de Almeida, G. M., de Souza, W., Fo.,... Carvalho, P. C. F. (2018). Grazing intensity determines pasture spatial heterogeneity and productivity in an integrated crop livestock system. Grassland Science, 65(1), 49-59. doi: 10.1111/grs.12209

Paris, W., Marchesan, R., Cecato, U., Martin, T. N., Ziech, M. F., \& Borges, G. D. S. (2012). Dynamics of yield and nutritional value for winter forage intercropping. Acta 
Scientiarum. Animal Sciences, 34(2), 109115. doi: 10.4025/actascianimsci.v34i2. 11507

Pontes, L. S., Barro, R. S., Savian, J. V., Berndt, A., Moletta, J. L., Porfírio-da-Silva, V.,... Faccio Carvalho, P. C. de. (2018). Performance and methane emissions by beef heifer grazing in temperate pastures and in integrated crop-livestock systems: the effect of shade and nitrogen fertilization. Agriculture, Ecosystems \& Environment, 253(1), 90-97. doi: 10.1016/j. agee.2017.11.009

Silveira, M. L., Liu, K., Sollenberger, L. E., Follett, R. F., \& Vendramini, J. M. B. (2013). Short-term effects of grazing intensity and nitrogen fertilization on soil organic carbon pools under perennial grass pastures in the southeastern USA. Soil Biology \& Biochemistry, 58(1), 42-49. doi: 10.1016/j.soilbio.2012.11.003

Sollenberger, L. E., Moore, J. E., Allen, V. G., \& Pedreira, C. G. (2005). Reporting forage allowance in grazing experiments. Crop Science, 45(3), 896-900. doi: 10.2135/ cropsci2004.0216
Souza, E. D., Costa, S. E. V. G. A., Lima, C. V. S. de, Anghinoni, I., Meurer, E. J., \& Carvalho, P. C. F. (2008). Carbono orgânico e fósforo microbiano em sistema de integração agricultura-pecuária submetido a diferentes intensidades de pastejo em plantio direto. Revista Brasileira de Ciência do Solo, 32(3), 1273-1282. doi: 10.1590/ S0100-06832008000300035

Taiz, L., \& Zeiger, E. (2013). Fisiologia vegetal (5a ed.). Porto Alegre: Artmed.

Van Soest, P. J. (1994). Nutritional ecology of the ruminant (2nd ed.). New York: Cornell University Press.

Wesp, C. D. L., Carvalho, P. C. F., Conte, O., Cadenazzi, M., Anghinoni, I., \& Bremm, C. (2016). Steers production in integrated crop-livestock systems: pasture management under different sward heights. Revista Ciência Agronômica, 47(1), 187-194. doi: 10.5935/1806-6690. 20160022 